These are some of the ways fiqh al-aqalliyāt may be able to provide balanced positions through innovative ijtihad as well as observance of the textual dispensations of Shariah and its higher purposes.

\title{
Notes
}

* Mohammad Hashim Kamali is the Founding CEO, International Institute of Advanced Islamic Studies (IAIS) Malaysia (Email: ceo@iais.org.my).

** Ahmad Badri bin Abdullah is Research Fellow at IAIS Malaysia (Email: badri@, iais.org.my).

\section{How the Qur'an Rejects Extremism}

\author{
Stephen B Young*
}

There is no Qur'anic justification for the murders, barbaric beheadings, and the maimings executed by supposedly faithful Muslims like ISIS loyalists, the Tsarnaev brothers in Boston, the Kouachi Brothers in Paris, or by the followers of Osama Bin Laden on September 11, 2001.

The crux of the Qur'anic case against such taking of life in the name of Islam is the wrongful appropriation of God's (Allah's) right and power, and committing murder and mayhem in the name of His religion. The Qur'an assigns death by retaliation to all cases of murder (2:178). It also provides "One who kills a human being without the latter being guilty of murder or corruption in the land, it would be as if he has killed the whole of humankind." (5:35). This clear enough, yet the wrong committed by these Sunni extremists also has an ideological dimension: it is idolatry, the worshipping of false gods and idols, in particular the putting of a person such as Al-Baghdadi or Osama Bin Laden, or oneself, in God's place as the arbiter of who should live and who deserves to die.

In Islamic terms the idolatry is called shirk.

God does not forgive those who serve other gods besides him. The Qur'anic guidance for this rule is found at Surah 4, at verse 48, and Surah 2 at verse 22.

The other month I tested my application of shirk to Islamic extremists with a Somali taxi driver taking me to the airport. He was a bit surprised to have an obviously non-Muslim turn the conversation to Qur'anic exegesis but readily agreed that the behavior of Islamic terrorists was, in his words, "very shirky."

I have been studying Qur'anic guidance for political action for some ten years now with highly reputed scholars at the International Islamic University, 
Malaysia. This University is one of the most accomplished institutions of higher education in the Muslim world attracting distinguished thinkers from many Islamic countries.

With little effort the problem of idolatry in Islam is quickly apprehended. The reasons why shirk is so wrong for Muslims are readily apparent in a reading of Qur'an.

God has all right and power. (Qur'an 2:109) To God do all questions go for decision. (Qur'an 3:109) His will prevails over ours we are to hold fast to God, guided to the straight path by him and not by our own desires and pretensions. It is not for us, says Qur'an, to rebel against God's power and authority. We were not created by Him to challenge His judgment. God's mastery of life, death, the alpha and omega of all things is His sole prerogative, an aspect of divine oneness and omnipotence (tawhid) over space and time.

He has no partner in this omnipotence. Certainly not any human person. God never gave us a commission to think for him or to believe that we are his equal. We are to put our trust in God, not in our fellow man. (Qur'an 5:11) If we think we are God's equal, we are wrong. Such thinking is Shirk.

He decides who is good and who is not. He, in His mercy and compassion, has the last word on the last day. God has reserved to Himself judgment as to the fate of those who deny the truth. (Qur'an 73: 11,12) No one dies unless God wills the death. (Qur'an 3:145) God will resolve differences among men. (Qur'an 5:49; 3:26) God pardons, punishes whom he pleases. (Qur'an 3:129)

The duty of us as human individuals is only to warn others. Their actual fate is in the hand of God. (Qur'an 88:23 - 26; 73:11)

Qur'an records that we are not to take life, which God has made sacred, except by way of justice and law. (Qur'an 6:151)

Second, Qur'an teaches that humans are prone to error. Our judgment can never be as good as God's. No human can never fully know what God wants or wills. Our thinking is contingent, limited, bounded by our own biases, fears, and passions. We can never share in God's perfection.

If we should obey the greater part of those on earth, says Qur'an, we would be led away from God's path. (Qur'an 6:116) The teachings of Qur'an promises woe to those who write scripture for personal gain and say "This is from God." $(2: 78)$

We are, Qur'an says, contentious, (Qur'an 18:54) given to injustice and ingratitude (Qur'an 14:34). We transgress in thinking ourselves our own masters. (Qur'an 96:6 - 7) We walk too proudly on the earth. (Qur'an 17:37) We mislead ourselves with our desires. (Qur'an 6:119)

Third, according to Qur'an, God enjoins charity, kindness, and peace among men. (Qur'an 4:114) God desires no injustice to mankind. (Qur'an 3:108) 
He gave life to humanity with his breath so that each of us contains some portion of God's potentials. An important capacity of God is to be merciful and compassionate.

To reject mercy or to close our hearts to compassion is to fall short of God's standard of the good. It is to replace God's judgment with our own pettiness.

But how are we to know what verdict on the life of another is just in God's mind? How can we know when God will be merciful and compassionate with those of us who have done wrong? We cannot rely on other humans with their limited capacities to instruct us on God's will in any given case of human accountability. Thus, under strict Qur'anic guidance the entire body of scholarship since the death of the Prophet - the work of many brilliant minds - cannot take precedence over the will of God.

Fourth, we read in Qur'an that God created humanity - men and women equally - to be his steward in creation, to see to its flourishing. (Qur'an 2:30; 15:29) The responsibility of a steward is to serve the master as a subordinate, not as a partner. The steward must always ask what the master wants, what serves his purposes.

God's purpose is that people will have faith and do good works.

Everything that we have by which we can act and leave our mark in the world has been given to us in trust by God. They are powers held in trust, not owned by ourselves for our own amusement. Therefore, our intelligence, emotions, dedication, skills, and money must not be governed by our own will but in deference to God's guidance. We are to strive in the work of having faith and doing good works as stewards of God that his creation will be ever pleasing to him and fruitful to us.

Fifth, how do we determine God's guidance? All human interpreters of Qur'an are only partially qualified as discoverers of God's will.

We may from time to time come under the influence of "vain conjectures and whims of [our] own words." (Qur'an 53:23)

A danger leading to misunderstanding of God put before us by Qur'an is the wiles of Satan who seeks to lead us far from right guidance. We need to be on our guard lest our pride and desires draw us closer to Satan's intrigues. Satan stirs up our vain desires. (Qur'an 4:120) Qur'an warns that for humans "Satan makes their deeds seem fair to them." (Qur'an 6:43) It is Satan's predilection to urge us towards the path of Shirk.

Thus we can demand of an Osama Bin Laden evidence that he is free from delusions and vanity. Similarly is not the self-promotion by Al Baghdadi of himself to the position of successor of the Prophet Mohammad (Caliph) only specious vainglory? What special revelation did either of these men ever get from God to guide their politics? 
Their personal reading of scripture does not necessarily make either of them God's trusted confident.

One check on our potential for getting it wrong is the opportunity for us to consult others and gain the benefit of their insights and understandings. Qur'an calls this sura. It provides checks on our intellectual limitations and emotional distractions.

The guidance that we should restrain our predilections by submitting to the checks and balances of others not only expands our range of understanding, it reminds us of our limitations, of our distance from the divine.

Rumi, the Sufi poet, captured the essence of rebellion against God present in shirk in his poem about Moses disparaging an apparent idiot who professed love for God. Rumi has God chastise Moses for his arrogance in thinking that he - the human - could step into the moral mind of the divine: "You have separated me from one of my own ... What seems wrong to you is right for him ... I am apart from all that."

We have no evidence that acts of Islamic extremism are divinely guided. To the contrary, all the evidence before us indicates that they are heinous excesses of damnable human arrogance and false pride. They are shirk.

\section{Notes}

* Stephen B Young holds a PhD in Law from Harvard University and is the Global Executive Director of the Caux Round Table (CRT), which brings together business leaders from Europe, Japan and other parts of Asia, as well as the United States, is committed to energising the role of business and industry as a vital force for innovative global change. Young is the author of Moral Capitalism (2004) and The Tradition of Human Rights in China and Vietnam (1989). He was previously Assistant Dean at the Harvard Law School and Dean of the Hamline University School of Law. He has taught at the School of Law and the Carlson School of Management at the University of Minnesota, the Minnesota State University, and the SASIN Graduate Institute of Business Administration in Chulalongkorn University, Bangkok. In 1966, Young discovered the UNESCO World Heritage site of Ban Chiang in Thailand. 